\title{
Effect of Neem (Azadirachta Indica) on Fertility in Male Rats
}

\author{
Khan $\mathrm{A}^{1}$, Begum $\mathrm{ZA}^{2}$, Khan $\mathrm{MI}^{3}$, Rahman $\mathrm{H}^{4}$, Banu $\mathrm{LA}^{5}$
}

\begin{abstract}
Background: Azadirachta indica locally known as neem has been claimed to possess antifertility properties by many investigators. Objective: The present study was designed to evaluate the antifertility effect of Azadirachta indica leaf powder in male rats. Methodology: The study was carried out in pharmacology and Therapeutic Department of Dhaka Medical College during the period of January 2008 to December 2008. Total number of 24 rats was divided into 4 groups. Group A was served as control, group B, C and D were treated by Azadirachta indica leaf powder orally, inj. testosterone I/M, \& Azadirachta indica leaf powder orally, inj. testosterone I/M respectively for 48 days. They were sacrificed on 49 day. Then morphological and histological study was done. Result: The result showed that the all of the Azadirachta indica leaf powder treated rats has significant antispermatognic effect as well as antiandrogenic effect. Conclusion: The Azadirachta indica leaf powder reduced motility and density of sperm and causes structural changes of leydig cells and seminiferous tubule. [J Shaheed Suhrawardy Med Coll, 2013;5(1):39-42]
\end{abstract}

Key words: Azadirachta indica, antifertility effect, antispermatognic, antiandrogenic, sperm count, animal study

Received: February 2012; Revised: December 2012; Accepted: April 2013

\section{Introduction}

Overpopulation is a global problem with grave implications for the future. It is now generally accepted that currently available methods of fertility regulation are inadequate to meet the varied and changing personal needs of couples at different times in their reproductive lives and in the widely different geographical, cultural and religious settings that exist around the world ${ }^{1}$.

The population projection of Bangladesh indicates that if the present rate $(1.9 \%)$ of population growth continues then the population will increase to $131.4,158.3,229.7$ and 846.1 millions in the years 2000, 2010, 2030 and 2100 respectively with the corresponding population density of 912, 1099, 1595 and 5875 per sq. $\mathrm{km}^{2}$. The contraceptive prevalence rate in Bangladesh $^{2}$ has increased from $8.0 \%$ percent in 1975 to
$58.0 \%$ of married women in 2004. The state of art at present offers a very restricted and far from satisfactory choice of methods, such as periodic abstinence, coitus interrupts, condoms and vasectomy for males. Hence there is a major need to develop safe, effective, reversible and acceptable fertility regulating agents in the male ${ }^{3}$.

Studies of various forms of neem for male contraception in different types of mammals have reported no changes in libido or hormonal function ${ }^{4}$. Neem bark extract and neem seed oil caused arrest of spermatogenesis within 2 months, with a decrease in the number of Leydig cells responsible for the manufacturing of testosterone ${ }^{5}$. Although neem treatment does not trigger a systemic autoimmune response to sperm, researchers speculate that a local immune response of some kind is responsible for its contraceptive effects ${ }^{6}$. So,

1. Dr. Asma Khan, Assistant Professor, Department of Pharmacology \& Therapeutics, Shaheed Suhrawardy Medical College, Dhaka

2. Prof. Dr. Zinnat Ara Begum, Professor \& Former Head, Department Pharmacology \& Therapeutics, Dhaka Medical College, Dhaka

3. Prof. Dr. Md. Ismail Khan, Vice- Principal \& Head, Department of Pharmacology \& Therapeutics, Dhaka Medical College, Dhaka

4. Dr. Hasanur Rahman, Assistant Professor, Department of Pharmacology \& Therapeutics, Dhaka Dental College, Dhaka

5. Prof. Dr. Layla Afroza Banu, Professor \& Head, Department of Pharmacology \& Therapeutics, Shaheed Suhrawardy Medical College, Dhaka

\section{Correspondence}

Dr. Asma Khan, Assistant Professor, Department of Pharmacology \& Therapeutics, Shaheed Suhrawardy medical College, Dhaka, Bangladesh; Email: asmakhan1171@gmail.com; Cell No.: +8802715166825

Contributions by authors: Dr. A Khan, Prof. Dr. ZA Begum and Prof. Dr. MI Khan were involved from the preparation of protocol upto completion of the research work. Prof. Dr. LA Banu, Dr. A Khan \& Dr. H Rahman were contributed in the manuscript writing. 
considering the above this present study was designed to evaluate the response of neem leaf powder in fertility of malerat

\section{Methodology}

Study Design: This experimental animal study was carried out in the Department of Pharmacology, Department of Microbiology and Departments of Pathology at Dhaka Medical College, Dhaka during the period of J anuary 2008 to December 2008 for a period of one (01) year. The study was carried out on a total number of twenty four (24), healthy adult Long Evans male rats of proven fertility. They were 10 to 12 weeks old, weighing between 170 to 200 grams.

Drug: Fresh mature deep green leaves of azadirachta indica (neem), Inj. Testosterone

Preparation of neem leaf powder: Fresh neem leave were collected from locality. Then cleaned and washed with plain tap water and kept in shade in normal room temperature dried in air by spreading them on large trays for 72 hours. Then neem leaves were grinded in to powder form by grinder. Then required amount of neem leave powder for each rat was dissolved in 1 cc of distilled water and administered orally by nasogastric tube

Intervention: Inj. testosterone was dissolved in olive oil and injected intramuscularly in the nape of the neck of rats between 10-11A.M. for 48 days. Experimental design: The animals were divided into four groups, each consisting of six rats. Group A consists of 6 rats and received $1 \mathrm{ml}$ of distilled water orally daily for 48 days and served as control. Group B consist of 6 rats and received $500 \mathrm{mg} / \mathrm{kg}$ body weight of leaf powder of Azadirachta indica orally daily for 48 days. Group $C$ consists of 6 rats and received $0.25 \mathrm{mg} / \mathrm{kg}$ body weight of $\mathrm{Inj}$. testosterone intramuscularly daily for 48 days. Group D consist of 6 rats and received $500 \mathrm{mg} / \mathrm{kg}$ body weight of leaf powder of Azadirachta indica orally and $0.25 \mathrm{mg} / \mathrm{kg}$ body weight of Inj. testosterone intramuscularly daily for 48 days. All the rats of group A, B, C, D were sacrificed on 49th day of experiment after mild ether anesthesia. Testes were collected in $10.0 \%$ formalin for preparation of histological slide to see the histological changes. Epididymis was collected for morphological study of sperm.

Outcome Measures: Morphological study was done by observing the density of sperm and motility of sperm. Histological study was performed by observing the number of seminiferous tubules per low power field (X10 objective) of microscope within testis and the number of Leydig cell per high power fiedd (X40 objective) within testis. The qualitative eval uation includes the study of the morphology of the seminiferous tubular epithelium amount of stromal tissue, regularity in the arrangement of the germinal cells and the presence of Leydig cells in the interstitial space. Measurement of the motility and number of sperms were counted by adopting the technique described by Taylor et al? .

Statistical analysis: All data were recorded systematically in preformed data collection sheet. Statistical analysis was performed by using SPSS for windows version 13.0. 95\% confidence limit was taken.

\section{Results}

Sperm density and motility of adult male rats: Table 1 showed that the mean $\pm S D$ number of sperm in group- $A$ (control), Group B (Azadirachta indica leaf powder treated), Group C (Inj testosterone treated), group-D (Azadirachta indica leaf powder and Inj. testosterone treated) were $19433.33 \pm 403.32$, $3516.67 \pm 407.02,19800.00 \pm 424.26$ and $17600.00 \pm 14.62$ respectively. Decrease in mean sperm density in the leaf powder of Azadirachta indica treated was highly significant $(P \varangle 0.001)$ in comparison with normal control group. Table I al so showed that the mean \pm SD of sperm motility in group A (control), Group B (Azadirachta indica leaf powder treated), Group C (Inj. testosterone treated), group-D (Azadirachta indica leaf powder and Inj testosterone treated) were $58.00 \pm 1.41 ; 23.17 \pm 1.94$; $59.33 \pm 1.75$ and $55.83 \pm 0.75$ respectively. There was highly significant $(\mathrm{P} \varangle 0.001)$ reduction in sperm motility in the experimental group receiving leaf powder of Azadirachta indica $500 \mathrm{mg} / \mathrm{kg} / \mathrm{b}$.w. orally daily for 48 days as compared to the control.

Table 1: The effect of leaf powder Azadirachta indica (AILP), testosterone and AILP \& testosterone on number of sperm and motility of sperm in male rat

\begin{tabular}{lcc}
\hline Groups & $\begin{array}{c}\text { Number of sperm } \\
\text { M ean } \pm \text { SD }\end{array}$ & $\begin{array}{c}\text { M otility of sperm } \\
\text { M ean } \pm \text { SD }\end{array}$ \\
\hline Group A & $19433.33 \pm 403.32$ & $58.00 \pm 1.41$ \\
Group B & $3516.67 \pm 407.02$ & $23.17 \pm 1.94$ \\
Group C & $19800.00 \pm 424.26$ & $59.33 \pm 1.75$ \\
Group D & $17600.00 \pm 1344.62$ & $55.83 \pm 0.75$ \\
\hline
\end{tabular}

Study of histology of testis: Table 2 showed the total number of seminiferous tubule in low power field (X 10 objectives) in the group A (control) , Group B (Azadirachta indica leaf powder treated), Group C (Inj testosterone treated) and group-D (Azadirachta indica leaf powder and Inj testosterone treated) were $-24.00 \pm 2.00 ; 9.17 \pm 1.47$; $30.00 \pm 2.28$ and $24.17 \pm 1.94$ respectively. Reduction of number of seminiferous tubules were statistically significant $(\mathrm{P} \varangle 0.001)$ in the groups receiving $500 \mathrm{mg} / \mathrm{kg}$ b.w. orally daily as compared to the control. The total number of Leydig cell in high power field (X 40 objectives) in the group A (control), Group B (Azadirachta indica leaf powder treated), Group C (Inj testosterone treated), group D who were treated with Azadirachta indica leaf powder and Inj.

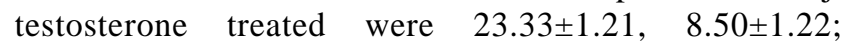
$29.00 \pm 2.10,23.50 \pm 1.05$ respectively. Reduction of number of Leydig cells were statistically significant $(\mathrm{P} \varangle 0.001)$ in the 
groups receiving $500 \mathrm{mg} / \mathrm{kg}$ b.w. orally dai ly as compared to the control.

Table 2: Effects of leaf powder Azadirachta indica, (AILP) testosterone and AILP and testosterone on number of tubule and Leydig cell

\begin{tabular}{lccl}
\hline $\begin{array}{l}\text { Groups } \\
(\mathbf{n}=6)\end{array}$ & $\begin{array}{c}\text { Number of Tubule } \\
\text { (Mean } \pm \text { SD) }\end{array}$ & $\begin{array}{c}\text { Number of L eydig cell } \\
\text { (Mean } \pm \text { SD) }\end{array}$ & p value \\
\hline Group A & $24.00 \pm 2.00$ & $23.33 \pm 1.21$ \\
Group B & $9.17 \pm 1.47 * * *$ & $8.50 \pm 1.22$ & \\
Group C & $30.00 \pm 2.28$ & $29.00 \pm 2.10$ & \\
Group D & $24.17 \pm 1.94$ & $23.50 \pm 1.05$ & \\
Discussion & &
\end{tabular}

The present study was carried out to evaluate the anti androgenic and anti spermatogenic effect of Azadirachta Indica leaf powder in adult male rats. Azadirachta Indica (neem) is available in all over Bangladesh and is reported to have mal eanti fertility effect ${ }^{8}$.

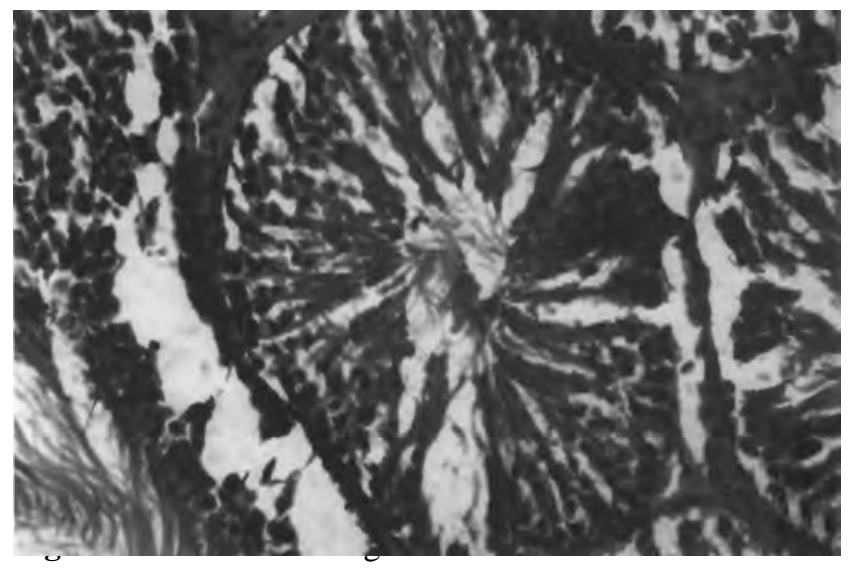

group (Magnification at 40X objectives)

The traditional basis for the diagnosis of male fertility in our country is by conventional semen analysis describing the number of spermatozoa present in the ejaculate, their morphology and their motility. In the present study it was observed that after administration of Azadirachta Indica there was a highly significant $(p<001)$ reduction in sperm density and motility.

Parshad ef $\mathrm{al}^{9}$ reported that the treatment with steroidal extract of Azadirachta Indica for 10 weeks causes increased number of headless sparmatozoa, significantly decreased $(p<0.01)$ motility of sperm. Ghosesawar et $\mathrm{a}^{10}$ showed that there is a decrease in the total sperm count in a study of Azadirachta indica treatment for 24 days in al bino rats which was comparable to this present study. In this present study the changes in histology of testis observed. Numbers of seminiferous tubule and Leydig cells were reduced. The reduction of the number of seminiferous tubule and Leydig cells were statistically significant $(p<001)$. Aladakatti and Ahammed ${ }^{11}$ studied the effect of Azadirachta Indica. They reported that the Azadirachta Indica leaves affected the morphology of Leydig cells, atrophic seminiferous tubule with widening inter cellular space. The number of reduction of Leydig cells was statistically significant ( $p \varangle 0.05$ ).

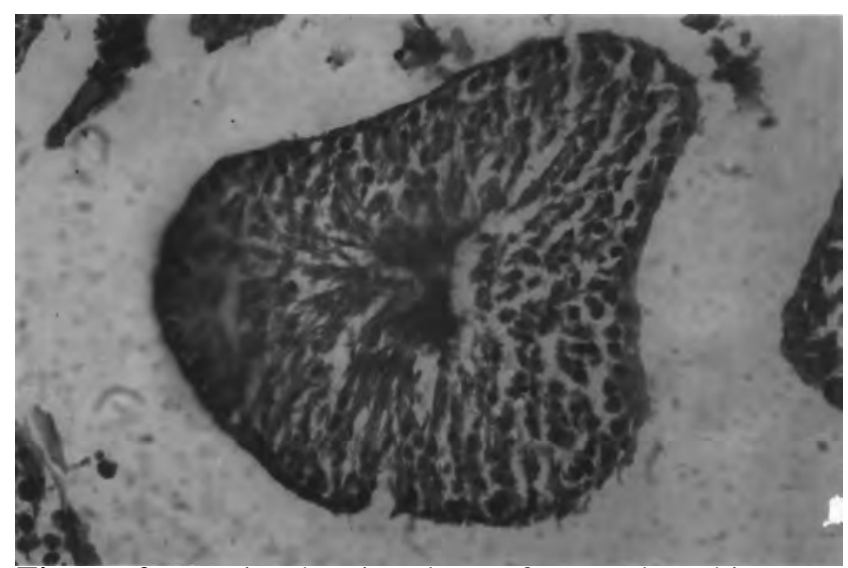

Figure 2: Testis showing loss of normal architecture, disorientation of various germ cell layer of Azadirachta Indica leaf powder treated group(Magnification at 40X objectives)

In the present study, the reduction in sperm density might attributed to the detrimental effects of the extract on seminiferous epithelium. The histological findings reveal ed that there was reduction in cell layers of the germinal epithelium and the seminiferous tubules were depopulated of sperms to a marked degree.

The effects thus elicited by these agents have been closely observed. Since the biological system of an individual or a group of individuals cannot be considered as a unique standard reference for the entire species due to individual or group variation and since there are limitations with the methods applied and variability response ${ }^{12}$. The results obtained in this study may not represent the actual effect. However, keeping all these points in mind, the results obtained in this investigation have been interpreted very carefully and cautiously. The present study only the preliminary basis of the anti fertility effect of Azadirachta Indica. The exact principle for such activity is not known ${ }^{13}$. The study invites further exploration of the specific anti fertility principle. A follow up pharmacological as well as biochemical study could emphasize the present findings to decide the ultimate value of Azadi rachta Indica leaf powder as a male ant fertility agent.

\section{Conclusion}

Therefore, on the basis of the overall findings in the present study, it can be concluded that Azadirachta Indica might play an important role as a male fertility regulating agent. Further studies are needed on this aspect to val idate the claim made in the present study.

\section{References}

1. Wang Y F. Male reproductive heal th research needs and research agenda: Asian and Chinese perspective Asian J Androl. 1999;1:13-20

2. Bangladesh Bureau of Statistics (BBS). Bangladesh health and Demographic Survey: Findings in Brief 1994 and 1995, Statistics Division under the Ministry of Planning, Dhaka A pril 1995, p-1; hereafter cited as BBS, Health and Demography

3. Noor F. Study of the effects of abroma augusta linn and cyproterone 
acetate on fertility in male rats [M Phil Thesis] BSMMU, 1992; 1-2

4. Jensen JT. Male contraception. Current Women Health Reports, 2002;2(5):338-45

5. Randhawa NS and BS Parmar (eds.) (1996) Neem. New Age International: New Delhi, India.

6. Lohiya NK, Manivannan B, Mishra PK, Pathak N. Vas deferens, a site of male contraception: an overview. Asian J Andrology, 2001;3 (2):87-95

7. Taylor GT, Weiss J, Frechmahh T, Haller J, Copulation induces an acute increase in epididymal sperm numbers rats. J Reprod Fert, 1985; 73:323-327

8. Aladakatti RH, Ahamed RN. Ultrastructural changes in Leydig cells and cauda epididymal spermatozoa induced by Azadirachta indica leaves in al bino rats. Phytother Res. 2005;19(9): 756-66

9. Parshad O, Gardner MT, The TL, Williams LAD, Fletcher CK, Antifertility Effects of Aqueous and Steroidal Extracts of Neem Leaf (Azadirachta indica) in Male Wistar Rats, Phytotherapy Research, 1998;11(2):168-170
10. Ghosesawar MG, Ahamed RN, Ahmed M, Aladakatti RH. Azadirachta indica adversely affects sperm parameters and fructose levels in vas deferens fluid of albino rats. J Basic Clin Physiol Pharmacol, 2003;14(4):387-95

11. Aladakatti RH, Ahamed RN, Ahmed M, Ghosesawar MG. Sperm parameters changes induced by Azadirachta indica in al bino rats. J Basic Clinical Physiology Pharmacology, 2001;12:69-76

12. Dehghan MH, Martin T, Dehghanan MA. Antifertility effect of Iranian neem seed alcoholic extract on epididymal sperm of mice. Iranian J Reproductive Med, 2005;3(2):83-85

13. Upadhyay SN, Dhawan S, Talwar GP, Antifertility effects of neem (Azadirachta indica) oil in male rats by single intra-vas administration: an alternate approach to vasectomy. J Andrology, 1993;14(4):275-81 